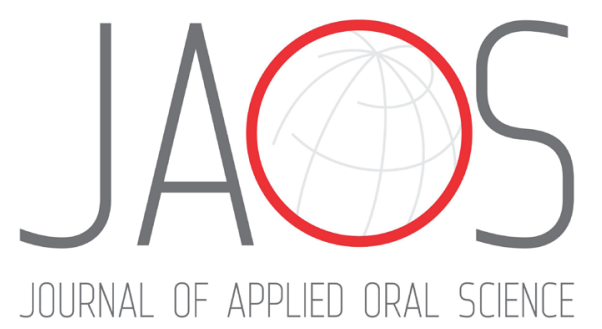

\title{
Bioactivity effects of extracellular matrix proteins on apical papilla cells
}

\section{Abstract}

Maria Luísa LEITE ${ }^{1}$ iD

Diana Gabriela SOARES ${ }^{2}$

Giovana ANOVAZZI ${ }^{3}$

Filipe Koon Wu MON ${ }^{4}$

Ester Alves Ferreira BORDINI ${ }^{1}$

Josimeri HEBLING ${ }^{3}$

Carlos Alberto DE SOUZA COSTA ${ }^{4}$
Submitted: January 21, 2021 Modification: April 3, 2021 Accepted: May 19, 2021

Corresponding address: Dr. Carlos Alberto de Souza Costa Rua Humaitá, 1680 - 14801-903 Araraquara - SP - Brasil. Phone: +55 (16) 3301-6477 e-mail:casouzac@foar.unesp.br
Potent signaling agents stimulate and guide pulp tissue regeneration, especially in endodontic treatment of teeth with incomplete root formation. Objective: This study evaluated the bioactive properties of low concentrations of extracellular matrix proteins on human apical papilla cells (hAPCs). Methodology: Different concentrations $(1,5$, and $10 \mu \mathrm{g} / \mathrm{mL})$ of fibronectin $(F N)$, laminin ( $L M)$, and type I collagen ( $C O L)$ were applied to the bottom of non-treated wells of sterilized 96 -well plates. Non-treated and pre-treated wells were used as negative (NC) and positive (PC) controls. After seeding the hAPCs $\left(5 \times 10^{3}\right.$ cells/well) on the different substrates, we assessed the following parameters: adhesion, proliferation, spreading, total collagen/type I collagen synthesis and gene expression (ITGA5, ITGAV, COL1A1, COL3A1) (ANOVA/Tukey; $\alpha=0.05$ ). Results: We observed greater attachment potential for cells on the FN substrate, with the effect depending on concentration. Concentrations of 5 and $10 \mu \mathrm{g} / \mathrm{mL}$ of FN yielded the highest cell proliferation, spreading and collagen synthesis values with $10 \mu \mathrm{g} / \mathrm{mL}$ concentration increasing the ITGA5, ITGAV, and COL1A1 expression compared with PC. LM (5 and $10 \mu \mathrm{g} / \mathrm{mL}$ ) showed higher bioactivity values than NC, but those were lower than PC, and COL showed no bioactivity at all. Conclusion: We conclude that $\mathrm{FN}$ at $10 \mu \mathrm{g} / \mathrm{mL}$ concentration exerted the most intense bioactive effects on hAPCs.

Keywords: Guided tissue regeneration. Dental pulp.Fibronectin.Laminin. Collagen.
${ }^{1}$ Universidade Estadual Paulista - UNESP, Faculdade de Odontologia de Araraquara, Departamento de Materiais Odontológicos e Prótese, Araraquara, SP, Brasil.

2Universidade de São Paulo, Faculdade de Odontologia de Bauru, Departamento de Dentística, Endodontia e Materiais Odontológicos, Bauru, SP, Brasil.

${ }^{3}$ Universidade Estadual Paulista - UNESP, Faculdade de Odontologia de Araraquara, Departamento de Morfologia e Clínica Infantil, Araraquara, SP, Brasil.

${ }^{4}$ Universidade Estadual Paulista - UNESP, Faculdade de Odontologia de Araraquara, Departamento de Fisiologia e Patologia, Araraquara, SP, Brasil.

The data that support the findings of this study are openly available in Mendeley Data at http://dx.doi. org/10.17632/knzz9hctcd.1 


\section{Introduction}

The concepts of tissue engineering were introduced to Dentistry in the last decade giving special attention to inducting pulp regeneration. ${ }^{1-4}$ The principles of regenerative endodontics are four: 1 . disinfection and detoxification of root canals; 2 . use of biomaterials as scaffold for cell adhesion, proliferation, and differentiation; 3. presence of cells with potential to regenerate a new tissue similar to the original; and 4. use of signaling agents to induce cell migration and enhance the bioactive action of the biomaterial. ${ }^{5,6}$

Two strategies emerged as the most promising therapies for tissue regeneration: cell approaches and cell-free approaches. 7,8 The first involves implanting pre-cultured cells associated with a biomaterial at the site of injury. The bioactive materials provide a porous three-dimensional structure and act as a temporary extracellular matrix where attached cells can grow to regenerate the tissue. The second, cellfree approaches, involve the use of biomaterials along potent signaling agents. When put into the injury site, these agents stimulate cell migration towards the site of interest, as well as their proliferation and differentiation, favoring tissue healing. ${ }^{7,8}$

Cell-free therapies seem to be interesting for teeth with incomplete root formation. A histopathological study of rat teeth with periapical lesion demonstrated a viable apical papilla was maintained even after 90 days of pulp necrosis. ${ }^{9}$ The apical papilla is known to have a rich source of stem cells. Therefore, biomaterials associated with potent signaling agents could be used to attract these cells into the root canal. These biomaterials should also promote adhesion, proliferation and differentiation of the stem cells along the entire length of the root canal, so they can synthetize new pulp-like tissue. ${ }^{1}$

Fibronectin (FN), laminin (LM) and type I collagen (COL) - examples of extracellular matrix proteins (ECMP) - have bioactive properties and were proposed as chemotactic and inducing agents, since scientists have described their proprieties in several biomedical fields. ${ }^{10-15}$ Previous studies showed FN, either associated with other proteins, or not, can mediate cell adhesion, migration, proliferation, and differentiation; while also helping in tissue formation, remodeling, repair and regeneration. ${ }^{11,13,15} \mathrm{LM}$ is a complex structure that also regulates cell adhesion, migration and proliferation. ${ }^{10,12}$ LM aids in maintaining cellular functions especially in the processes of reeptelialization and angiogenesis. ${ }^{10} \mathrm{COL}$ is a common protein that surround cells throughout the body, with over $90 \%$ of this protein being type I. COL can be used to mimic the natural cell environment, and under specific conditions, is effective in promoting stem cell differentiation and growth. ${ }^{13,16}$

One study characterized the dehydrated human umbilical cord (DHUc) in terms of tissue composition and evaluated its in vitro and in vivo effects. ${ }^{14}$ The authors observed the presence of $\mathrm{COL}$, hyaluronic acid, FN and LM, among other proteins, which included growth factors, inflammatory modulators and cell signaling regulators in the DHUc. They observed increased migration of fibroblasts, and higher level of mesenchymal stem cell proliferation, associated with induction of angiogenic potential in vitro depending on concentration when cells were treated with DHUc. When implanted into subcutaneous tissue of rats, this biomaterial proved to be biocompatible and biodegradable. ${ }^{14}$ Researchers have reported decellularized human dental pulp, which maintains several proteins of this specialized connective tissue, like $\mathrm{COL}, \mathrm{FN}$ and $\mathrm{LN}$, is a suitable scaffold to mimic the complexity of the dental pulp extracellular matrix. ${ }^{17,18}$ Decellularized biological scaffolds allow stem cells from apical papilla ${ }^{17}$ as well as human dental pulp stem cells ${ }^{18}$ to attach and proliferate while being stimulated to differentiate into odontoblast-like cells close to the dentin substrate. ${ }^{18}$

Despite the extracellular matrix proteins role on pulp regeneration and formation of a new pulp-like tissue, the data concerning the influence of FN, LN and COL on the metabolism and function of human apical papilla cells (hAPCs) - especially when young teeth with incomplete root formation have lost their vitality is scarce. Thus, this in vitro study assessed the effects of FN, LM and COL on the adhesion, proliferation and spreading of hAPCs as well as on the potential of these cells to synthesize collagen and express genes related with pulp regeneration.

\section{Methodology}

Firstly, approval of the research was obtained from the Research Ethics Committee of Araraquara School of Dentistry/UNESP, São Paulo, Brazil (protocol No. $80806617.3 .0000 .5416)$ as well as signed terms of 
informed consent from patients and their guardians, according to the Declaration of Helsinki. Subsequently the hAPCs were obtained from the apical papilla of four healthy third molars with incomplete root formation. These teeth were provided by volunteers aged 16 to 18 years old, of both sexes, who were patients at the surgery clinic. The teeth were extracted for orthodontic reasons. To obtain the primary culture of hAPCs, the extracted teeth were immediately immersed in Minimum Essential Medium Eagle Aphaculture medium (a-MEM; GIBCO, Carlsbad, CA, USA) supplemented with antibiotic and antifungal (100 $\mathrm{U} / \mathrm{mL}$ penicillin, $100 \mathrm{~g} / \mathrm{mL}$ streptomycin, and 0.25 $\mathrm{g} / \mathrm{mL}$ amphotericin; GIBCO) at $4^{\circ} \mathrm{C}$, for 1 hour. In a procedure performed in a biosafety cabinet (Bio Protector 12 Plus; VECO, Campinas, SP, Brazil), the papilla was sectioned with a sterile scalpel blade, at the apical limit of the root. This tissue was transferred to a $1.5 \mathrm{~mL}$ tube containing phosphate buffered saline (PBS 1X; GIBCO), followed by mechanical disintegration with sterile surgical scissors. Then, the apical papilla fragments were incubated in $\alpha$-MEM containing $3 \mathrm{mg} /$ $\mathrm{mL}$ type I collagenase (Sigma-Aldrich, Saint Louis, MO, USA) at $37^{\circ} \mathrm{C}$ and $5 \% \mathrm{CO}_{2}$ for $2 \mathrm{~h}$. After this period, the cells were centrifuged, washed with PBS $1 \mathrm{X}$, and later seeded in wells of a 6-well plate (Corning, Tewksbury, MA, USA); for the seeding, we used a-MEM supplement with $10 \%$ fetal bovine serum (FBS), 100 $\mathrm{U} / \mathrm{mL}$ penicillin, $100 \mathrm{~g} / \mathrm{mL}$ streptomycin, and $0.25 \mathrm{~g} /$ $\mathrm{mL}$ amphotericin (GIBCO). After $3 \mathrm{~h}$ incubation, the supernatant was discarded and the cells that remained attached to the bottom of the wells were sub-cultured in $100 \times 15 \mathrm{~mm}$ petri dishes (Corning). Cells at passage 3 to 5 were used in the experiments.

Fibronectin $(2.0 \mathrm{mg} / \mathrm{mL}$, bovine plasma; SigmaAldrich), laminin ( $1 \mathrm{mg} / \mathrm{mL}$, Engelbreth-Holm-Swarm lathyritic mouse tumor; Santa Cruz Biotechnology), and type I collagen $(3.67 \mathrm{mg} / \mathrm{mL}$, rat trial; Corning, Bedford, MA, USA) were used in this study. These ECMps were diluted in PBS $1 \mathrm{X}$ to obtain concentrations of 1,5 and $10 \mu \mathrm{g} / \mathrm{mL}$ that were applied $(50 \mu \mathrm{L})$ to the bottom of wells without pretreatment of sterilized polystyrene 96-well plates (Corning; Product Number: 3370). The 96-well plates were then centrifuged at $1500 \mathrm{rpm}$ at $4^{\circ} \mathrm{C}$ for $10 \mathrm{~min}$. After keeping the plates at $4^{\circ} \mathrm{C}$ for $18 \mathrm{~h}$, the remaining material was aspirated. These plates were incubated with $0.5 \%$ bovine serum albumin (BSA; Santa Cruz Biotechnology) for 10 min to block the uncoated surface, ${ }^{19,20}$ followed by washing with PBS $1 \mathrm{X}$ at $37^{\circ} \mathrm{C}$. All these steps were performed for both negative (NC) and positive (PC) control groups. In the NC, PBS solution without ECMp was applied to the bottom of non-pretreated wells of sterilized polystyrene 96-well plates (Corning; Product Number: 3370). In the PC, APBS without ECMp solution was applied to the bottom of wells of polystyrene 96 -well plates that were pre-treated by the manufacturer for cell culture purpose (Corning; Product Number: 3395). Table 1 shows all groups established according to the polystyrene 96-well plates used, as well as the type and concentration of ECMp.

After performing the treatments of wells with ECMp, the hAPCs $\left(5 \times 10^{3}\right.$ cells/well) were seeded in the respective wells and incubated at $37^{\circ} \mathrm{C}$ and $5 \%$ $\mathrm{CO}_{2}$ for up to 5 days, with the culture medium being changed every $48 \mathrm{~h}$. Then, the bioactivity parameters were evaluated. All assays were performed twice to ensure the data reproducibility.

Cell adhesion: Since the non-treated 96-well plates did not allow cell attachment on the bottom of the wells, the attachment potential of the microplate treated with different concentrations of ECMp was assessed. For this purpose, protocols of dynamic systems, in which microchannels are treated with proteins to induce cell chemotaxis, ${ }^{19-21}$ were adapted to this study. After $24 \mathrm{~h}$ of applying cell suspensions to the plate wells $(n=6)$, the hAPCs capable of migrating and attaching to the bottom of wells were evaluated under a light microscope. For this purpose, the cells were fixed with $2.5 \%$ glutaraldehyde for $2 \mathrm{~h}$, washed with distilled water and stained with $0.1 \%$ crystal violet for $15 \mathrm{~min}$. For quantitative analysis, photographs

Table 1- Experimental and control groups according to type of polystyrene 96-well plate and type and concentration of extracellular matrix protein (ECMp)

\begin{tabular}{cccc}
\hline Groups & $\begin{array}{c}\text { Pre-treated } \\
\text { wells by the } \\
\text { manufacture }\end{array}$ & ECMp & $\begin{array}{c}\text { Concentration } \\
(\mu \mathrm{g} / \mathrm{mL})\end{array}$ \\
\hline $\begin{array}{c}\text { NC (negative } \\
\text { control) }\end{array}$ & - & - & 0 \\
$\begin{array}{c}\text { PC (positive } \\
\text { control) }\end{array}$ & + & Fibronectin & 0 \\
\hline FN1 & - & Fibronectin & 5 \\
\hline FN5 & - & Fibronectin & 10 \\
\hline FN10 & - & Laminin & 1 \\
\hline LM1 & - & Laminin & 5 \\
\hline LM5 & - & Laminin & 10 \\
\hline LM10 & - & Type I collagen & 1 \\
\hline COL1 & - & Type I collagen & 5 \\
\hline COL5 & - & Type I collagen & 10 \\
\hline COL10 & - & & \\
\hline
\end{tabular}


(1 field from the central region of each well of the microplate; $10 \times$ magnification) were obtained with a camera (Olympus C5060, Miami, FL, USA) coupled to a microscope (Olympus BX51, Miami, FL, USA). The images were evaluated using Image $] 1.45 \mathrm{~S}$ software (Wayne Rasband, National Institutes of Health, USA) to count the number of cells on each image.

Cell proliferation: This analysis was performed by the MTT assay $(n=6)$. After intervals of 1,3 and 5 days in $\alpha$-MEM, cells were incubated for $4 \mathrm{~h}$ in a-MEM supplemented with $10 \%$ MTT solution (5 mg/ $\mathrm{mL}$; Sigma-Aldrich). ${ }^{22}$ Then, the formazan crystals produced were dissolved in acidified isopropanol and absorbance of the resulting solution was measured at $570 \mathrm{~nm}$ (Synergy H1, Biotek, Winooski, VT, USA). The mean absorbance value obtained in the negative control group over the 1-day period was considered $100 \%$ cell proliferation. This parameter was used to determine the percentage of viability for the other groups.

Cell spreading: For this analysis $(n=4)$, after intervals of 1,3 and 5 days in $\alpha$-MEM, the cells were fixed in $4 \%$ paraformaldehyde, permeabilized in $0.1 \%$ Triton X-100 (Sigma-Aldrich) and incubated with Actin Red 555 probe (Life Technologies; Grand Island, NY, USA) in $2 \%$ BSA $(1: 20)$ to detect the actin filaments. After washing the cells with PBS, they were incubated with Hoescht (1:5000; Invitrogen, Carlsbad, CA, USA) for $15 \mathrm{~min}$ for nuclear counter-staining. ${ }^{23}$ The $\mathrm{F}$-actin assay was then analyzed using a fluorescence microscope (Leica DM 5500B).

Total collagen synthesis: The cells were cultured for 5 days in a-MEM without FBS, and the culture medium was collected and replaced every $48 \mathrm{~h}$. The pool of collected culture medium of each sample was stored at $-20^{\circ} \mathrm{C}$ until the Sirius Red assay was performed $(n=6)$. For this purpose, the culture was transferred to 1.5 $\mathrm{mL}$ tubes containing Direct Red solution in saturated picric acid $(0.1 \%)$, and then incubated for 1 hour, under agitation at $400 \mathrm{rpm}$, in a dry bath at $25^{\circ} \mathrm{C}$. The tubes were centrifuged, the supernatant was discarded, and $0.01 \mathrm{M}$ hydrochloric acid was added. The tubes were centrifuged again, the supernatant was discarded, followed by the addition of $0.5 \mathrm{M}$ sodium hydroxide to solubilize the precipitated material. ${ }^{24}$ The resulting solution from each sample was subjected to absorbance analysis in a spectrophotometer at 555 $\mathrm{nm}$ (Synergy H1). ${ }^{24}$ The percentage of total collagen synthesis for each sample was calculated based on the mean absorbance values of the negative control group.

Type I collagen synthesis: The medium pool collected in the previous analysis $(n=6)$ was also used to evaluate the type I collagen synthesis (COL-I), which was detected by enzyme-linked immunosorbent (ELISA) assay performed with a standardized kit (Duoset human COL-I - R\&D Systems, Minneapolis, MN, USA), according to manufacturer's instructions. For this purpose, 96-well plates for ELISA (Corning) were treated with $4 \mu \mathrm{g} / \mathrm{mL}$ of Capture Antibody and incubated overnight. After this period, the wells were incubated with Reagent Diluent $1 \mathrm{X}$ for 1 hour. Then, standardized aliquots of the samples and standard curve points were applied and incubated for $2 \mathrm{~h}$. After this, the wells were maintained with $100 \mathrm{ng} /$ $\mathrm{mL}$ Detection Solution for $2 \mathrm{~h}$, followed by incubation in dark room, with $2.5 \%$ Streptavidin-HRP, for 20 min. The wells were washed with Wash Solution $1 \mathrm{X}$ between all steps described. Finally, Substrate Solution (color reagent $A+$ color regent $B ; 1: 1$ ) was applied and after 20 minutes, the Stop Solution was added. The absorbance reading was performed at a wavelength of $450 \mathrm{~nm}$ in a spectrophotometer (Synergy $\mathrm{H} 1$ ). The concentration of type I collagen for each sample was determined according to the standard curve. The percentage of type I collagen synthesis for each sample was calculated based on the average concentration values, in $\mathrm{ng} / \mathrm{mL}$ of the positive control group.

Reverse transcription followed by quantitative polymerase chain reaction (RT-qPCR): After incubating the cells in $\alpha$-MEM for 5 days $(n=4)$, the RNAqueous kit (Ambion, Grand Island, NY, USA) was used to isolate the RNA in accordance with the manufacturer's instructions. To obtain sufficient RNA for the reaction, a pool of cells obtained from two wells was used for each group. Then, $500 \mathrm{ng}$ of total RNA associated with random hexamer primers and Moloney leukemia virus reverse transcriptase were used to determine the cDNA synthesis $(n=4)$, according to the instructions of the High Capacity RT kit supplier (Applied Biosystems, Foster City, CA, USA). For the gene expression of ITGA5, ITGAV, COL1A1 and COL3A1 (Figure 1) by qPCR was performed, using pre-designed sets of primers and probes (Gene expression assays, Applied Biosystems) to detect target genes by the TaqMan system (TaqMan Universal PCR Master Mix, Applied Biosystems) with the StepOne Plus equipment (Applied Biosystems). In addition, the cycling conditions optimized by the 
manufacturer were used, and the cycle threshold (CT) values for each sample were calculated using the thermal cycler software and analyzed using the $2^{\Delta \Delta C T}$ method. The results were normalized according to the constitutive gene expression (GAPDH) and expressed as a fold change in relation to the positive control.

The data from cell adhesion, viability, total protein synthesis, type I collagen synthesis, and RT-qPCR assays were evaluated for adherence to the normal curve (Shapiro-Wilk test, $p>0.05$ ) and homoscedasticity (Levene test, $p>0.05$ ). Then, the data were submitted to the one-way or two-way ANOVA test, followed by the Tukey post-hoc test by means of SPSS 20.0 software (SPSS Inc., Chicago, IL, USA). All statistical inferences were based on the $5 \%$ level of significance. The DSS Research calculator was used to calculate the statistical power of the samples, according to $\mathrm{Kim}^{25}$ (2016), which showed a power level $>95.0 \%$ for each analysis. The cell spreading images were analyzed descriptively.

\begin{tabular}{|c|c|c|}
\hline Gene & Assay ID & Encoded protein \\
\hline COL1A1 & Hs01076756_g1 & Type I collagen \\
\hline COL3A1 & Hs00943809_m1 & Type III collagen \\
\hline ITGA5 & Hs01547673_m1 & Integrin $\alpha 5$ \\
\hline ITGAV & Hs00233808_m1 & Integrin $\alpha \mathrm{V}$ \\
\hline GAPDH & Hs02786624_g1 & $\begin{array}{c}\text { Glyceraldehyde-3-Phosphate } \\
\text { Dehydrogenase (GAPDH; } \\
\text { constitutive gene) }\end{array}$ \\
\hline
\end{tabular}

Figure 1- TaqMan assays used to analyze gene expression

\section{Results}

Cell adhesion: As demonstrated in Figure 2A and $B$, the highest attachment potential occurred in Group FN10, followed by Groups FN5, FN1, PC, LM10, and LM5 ( $p<0.05)$. No significant difference was observed between Groups LM1, COL1, COL5, and COL10 and Group NC ( $p>0.05)$.

Cell proliferation: Figure 3 shows increased cell proliferation occurred over time-points for all groups $(p<0.05)$, except for those treated with type I collagen and Group NC ( $p>0.05)$. The best cell viability result was observed in the groups treated with 5 or $10 \mu \mathrm{g} /$ $\mathrm{mL}$ of $\mathrm{FN}$ after intervals of 1,3 and 5 days $(\mathrm{p}<0.05)$. At the last time-point, this increase was 30x higher when compared with Group NC, 1.7x higher than in Group PC, and 2.7x higher than the group treated with $10 \mu \mathrm{g} / \mathrm{mL}$ LM. The group FN1 also showed higher cell viability values than the group LM10 in all time-points $(p<0.05)$.

Cell spreading: Figure 4 displays how cells seeded on the bottom of the wells treated with 5 or $10 \mu \mathrm{g} /$ $\mathrm{mL}$ of FN had better spreading on the substrate and a higher rate of proliferation over the time-points. In the groups treated with COL and in Group NC, lower numbers of cells organized in clusters exhibiting contracted cytoskeletons remained attached to the wells bottom.

Total collagen synthesis: Figure 5A shows increase in the total collagen synthesis occurred in Groups FN10 and FN5, followed by Groups PC and LM10 in comparison with Group NC ( $p<0.05)$.
A

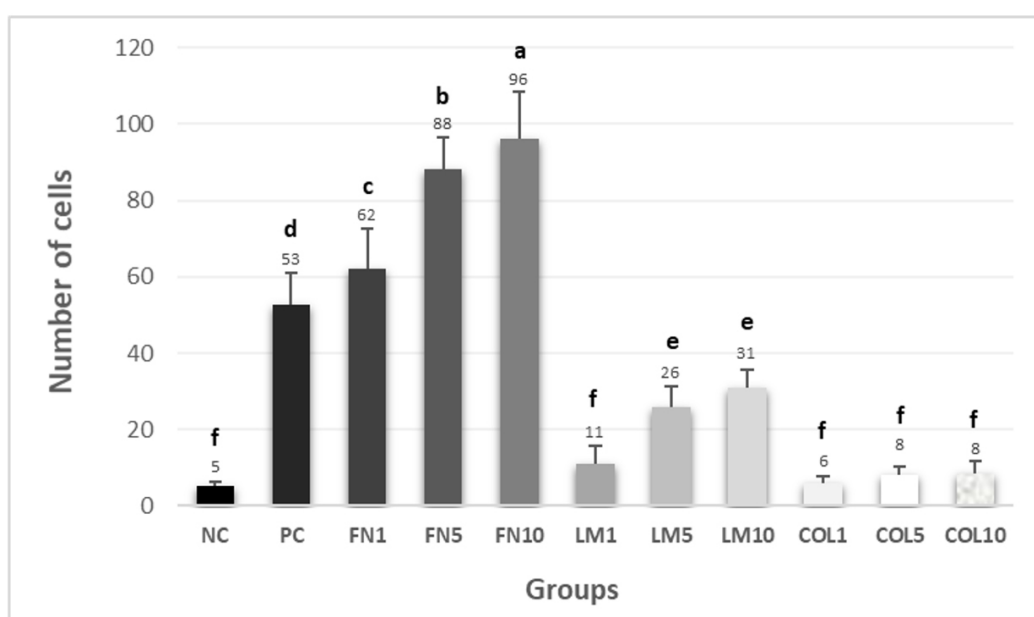

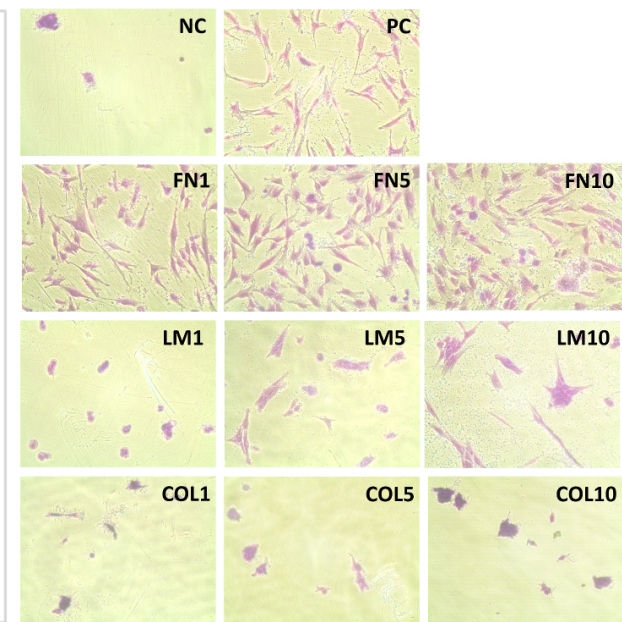

Figure 2- Cell adhesion assay. (A) Mean and standard deviation of the number of cells adhered to the bottom plate treated according to the group. Different letters demonstrate a significant difference between groups ( $n=6$; one-way ANOVA/Tukey tests; $\alpha=0.05$ ). (B) Representative images of the cell adhesion 


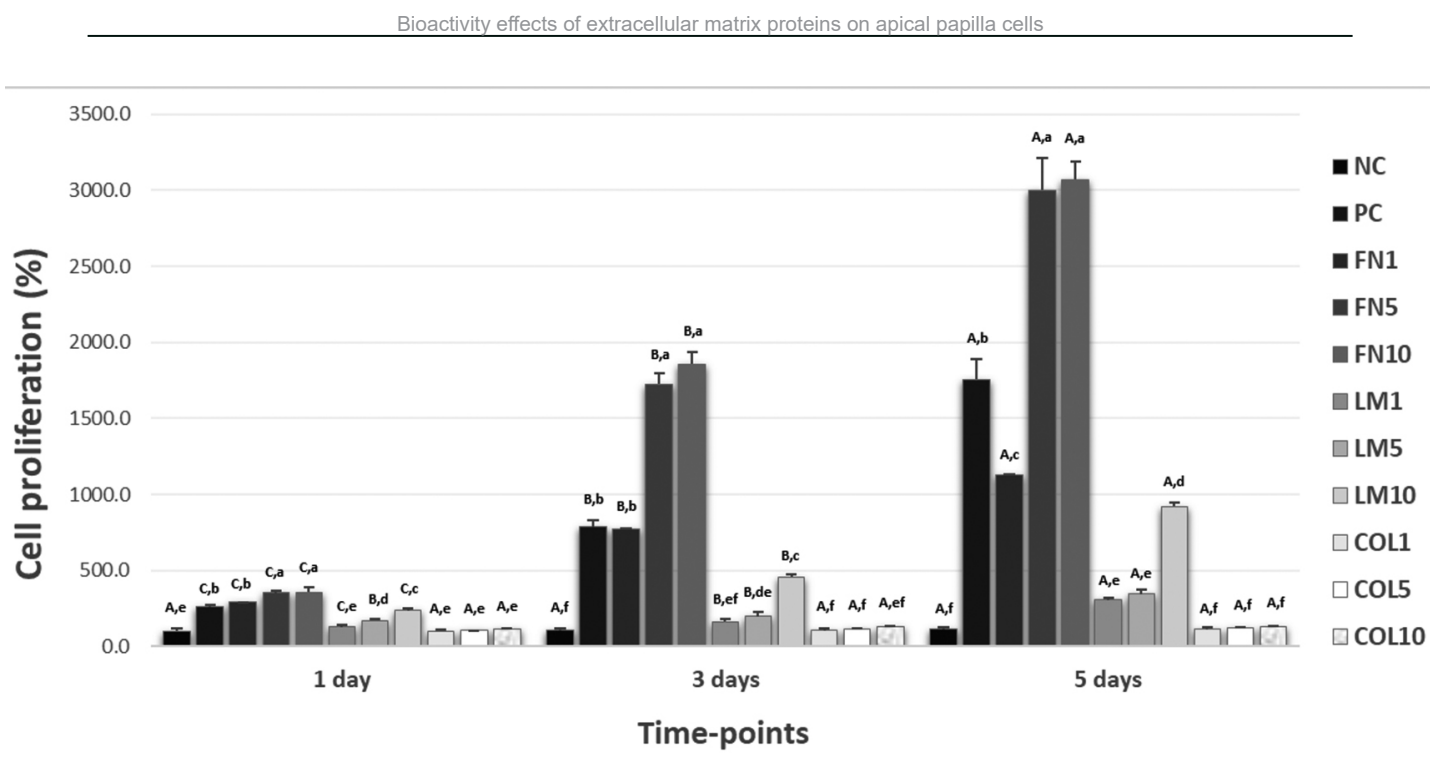

Figure 3- Mean and standard deviation of cell proliferation values ( $n=6$; two-way ANOVA/Tukey tests; $\alpha=0.05)$. Different capital letters indicate a significant difference between the time-points for each group. Different lowercase letters demonstrate a significant difference between groups in each time-point

Type I collagen synthesis: Figure 5B demonstrates that more type I collagen was synthesized in Group FN10 $(p<0.05)$, followed by Groups FN5 and PC $(p<0.05)$, which showed no significant difference between them $(p>0.05)$. Groups LM5 and LM10 showed lower values of type I collagen synthesis in comparison with Group PC $(p<0.05)$, but higher than those observed for Group NC $(p<0.05)$.

RT-qPCR: Figure 6A-D shows higher levels of ITGA5, ITGAV, and COL1A1 gene expression occurred in Group FN10 in comparison with Group PC $(p<0.05)$. However, FN10 and PC groups COL3A1 gene expression had no significant difference $(p>0.05)$. Group FN5 showed no statistical difference when compared with Group PC for all evaluated genes ( $p>0.05$ ), and Groups LM5 and LM10 demonstrated lower values of gene expression than Group PC $(p<0.05)$.

\section{Discussion}

The application of tissue engineering concepts for the purpose of pulp tissue regeneration has been relevant, especially in endodontic treatment of teeth with incomplete root formation. The thin and fragile walls of the root canal, associated with the short length of the root, make these teeth susceptible to fracturing under the forces to which they are submitted. 7,26 Conservative treatments that aim to stimulate cell migration from apical papilla into the root canal and allow the synthesis of a new pulp-like tissue seem to be an interesting alternative that would allow the return of tooth vitality and continuity of root formation. For this purpose, the use of a potent signaling agent is crucial to stimulate and guide tissue regeneration. ${ }^{5,6}$ Studies have shown extracellular matrix proteins in concentrations between 0.5 to $100 \mu \mathrm{g} / \mathrm{mL}$ can act as a bioactive agent on cells from different sources. ${ }^{27,30}$ Therefore, in the present study, we assessed the biological activities of low concentrations of ECMp (fibronectin, laminin and type I collagen) on hAPCs.

Type I collagen can regulate the cell behavior by specific signals and trigger several biological activities essential for tissue development and homeostasis. ${ }^{11}$ However, the different concentrations of $\mathrm{COL}$ tested in this investigation showed no bioactive potential on the hAPCs. As observed in the negative control, only a few cells remained attached to the $\mathrm{COL}$ over the time-points. These cells, which exhibited cytoplasm contraction, were organized in clusters. Parisi, et al. ${ }^{15}$ (2020) reported that adhesion represents both the interaction between cells and the substrate on which they were seeded, and the interaction and communication among surrounding cells, which activate the mechanisms of proliferation and differentiation. These authors showed that lack of cell adhesion to the substrate and interaction with surrounding cells resulted in apoptosis..$^{15}$ Therefore, according to the data obtained in the present study, and given the relevant role of collagen in different cell functions, ${ }^{4,11,31-33}$ we suggest that the concentrations of type I collagen tested on the hAPCs were insufficient to stimulate cell adhesion, proliferation and spreading. As the study aimed to evaluate and compare the bioactive effects of low dosages of ECMp, the same concentrations of FN, LM and COL were evaluated 

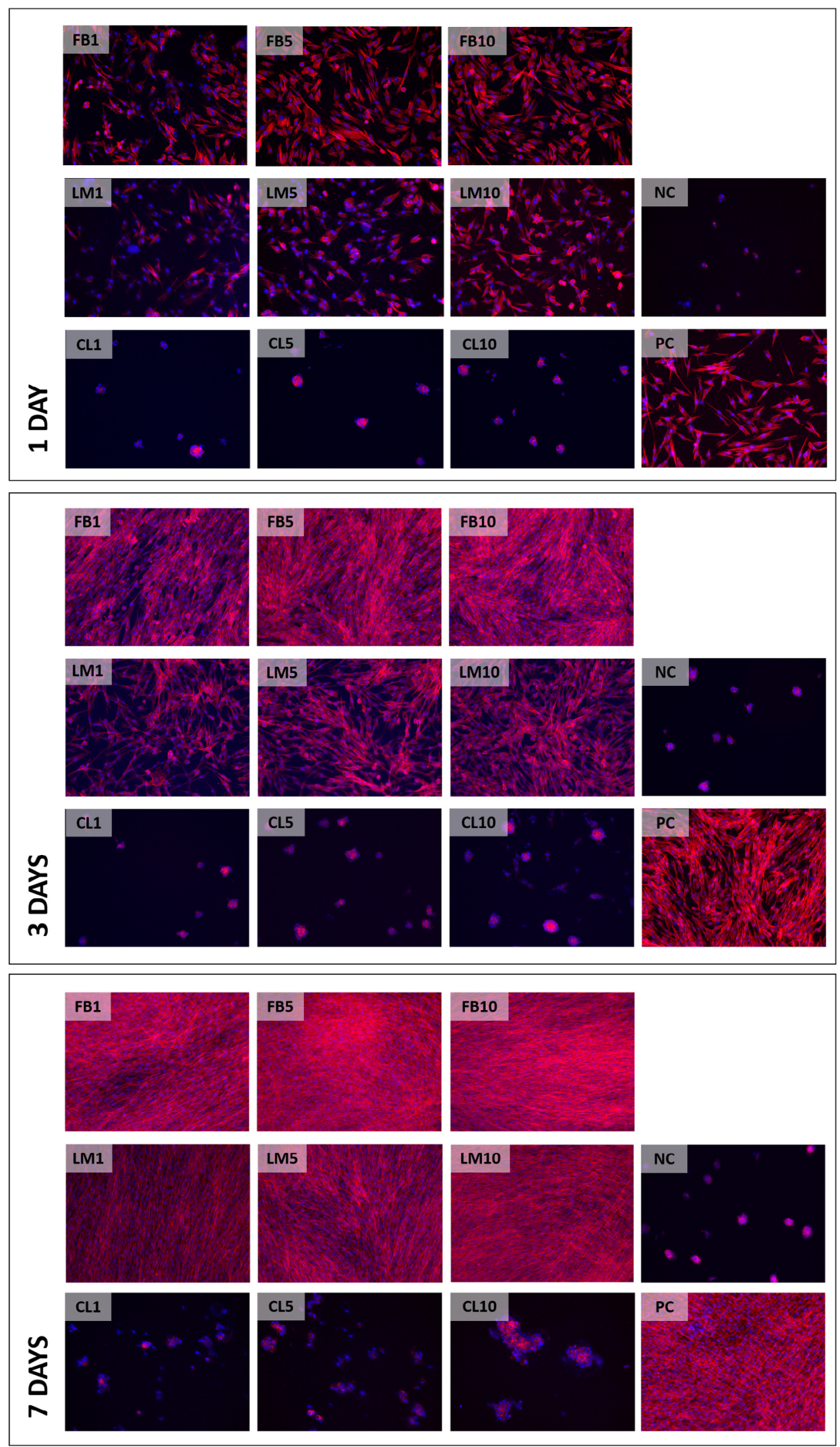

Figure 4- Representative images of F-actin assay (10x). Red fluorescence indicates the actin filaments. Blue fluorescence indicates the cell nucleus

on hAPCs. However, based upon the negative data obtained for $\mathrm{COL}$, we recommend the assessment of higher concentrations of this type of ECMp on hAPCs in future studies.
Although the cell attachment of LM was lower in comparison with the positive control, we observed a dose-response effect on hAPCs when using different concentrations of this protein. The assays using 5 
A

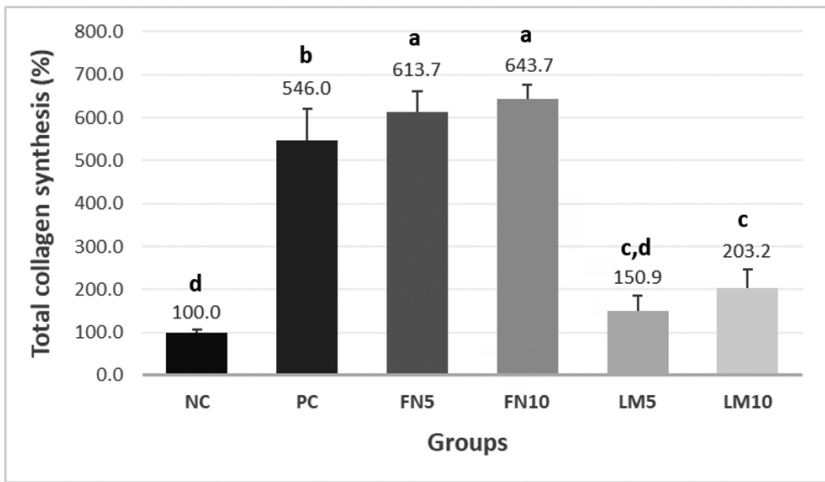

B

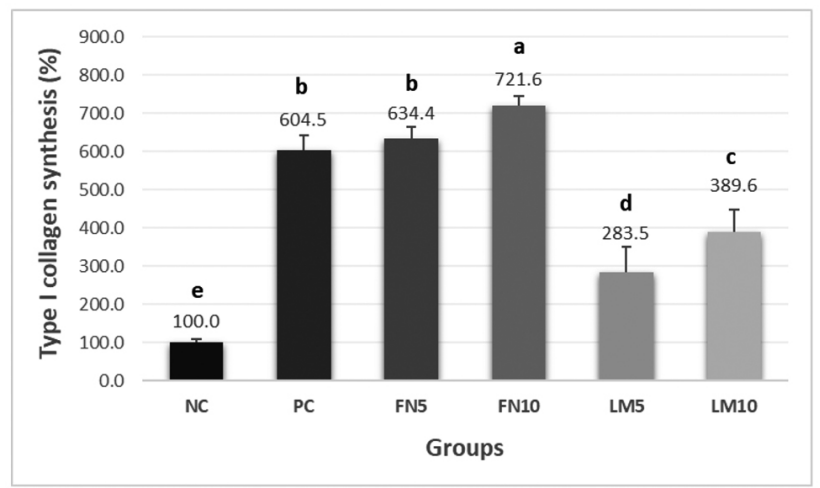

Figure 5- Mean and standard deviation of total collagen (A) and type I collagen (B) synthesis values ( $\mathrm{n}=6$; one-way ANOVA/Tukey tests: $\alpha=0.05$ ). Different letters demonstrate a significant difference between groups

(a)

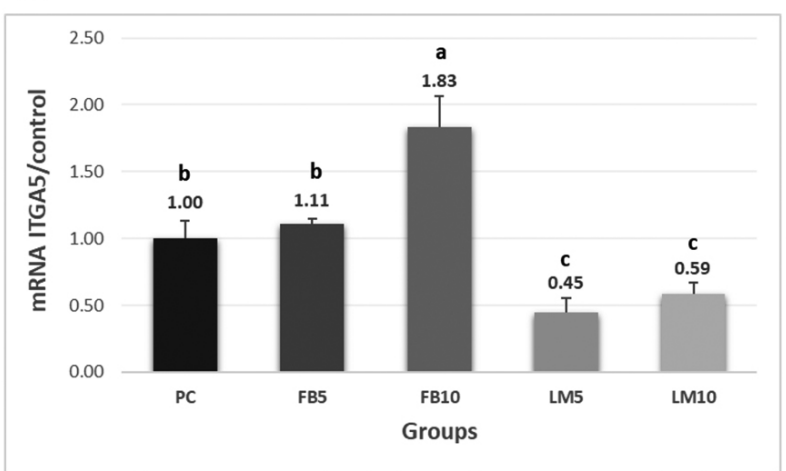

(c)

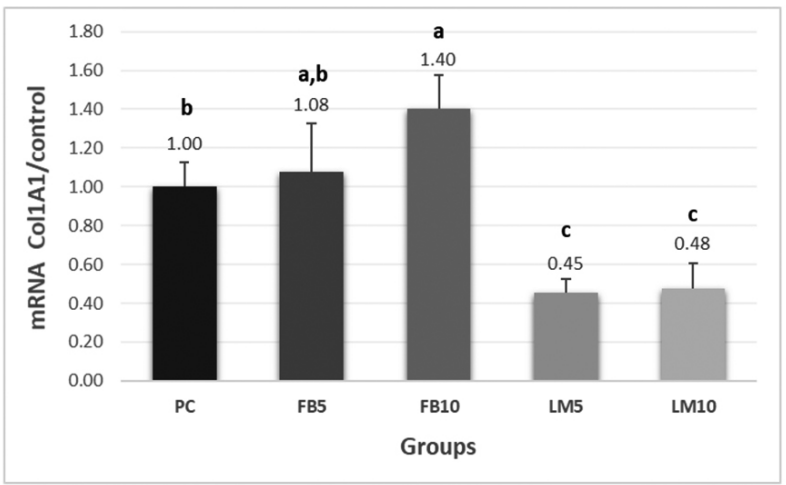

(b)

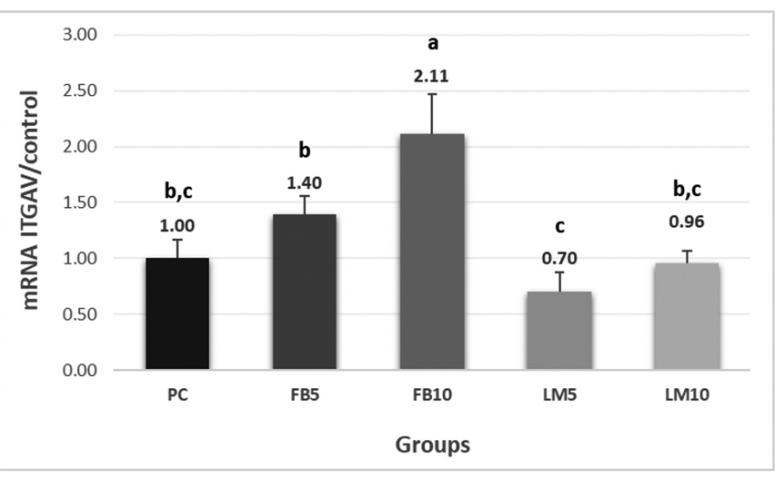

(d)

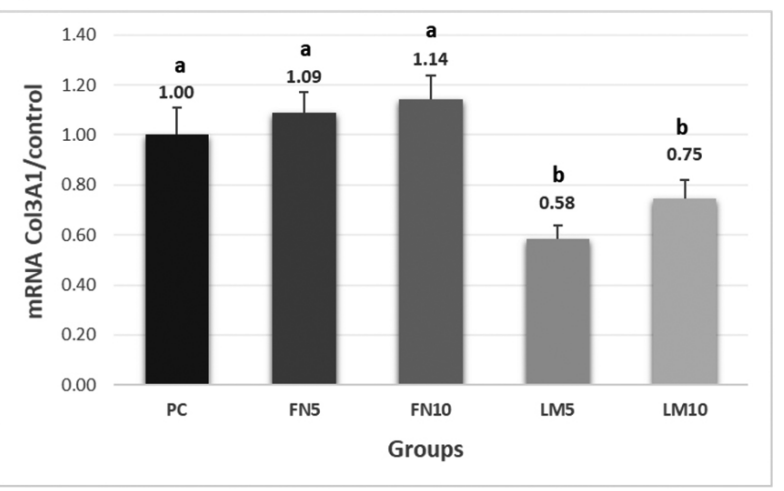

Figure 6- Mean and standard deviation of mRNA gene expression values of the ITGA5 (A), ITGAV (B), COL1A1 (C) and COL3A1 (D) markers ( $n=4$; one-way ANOVA/Tukey tests; $\alpha=0.05$ ). Different letters demonstrate a significant difference between groups

and $10 \mu \mathrm{g} / \mathrm{mL}$ of $\mathrm{LM}$ yielded greater cell adhesion, proliferation and spreading in comparison with the negative control. A recent study showed LM expression in blood vessels regulated the viability and migration of oligodendrocyte precursor cells via $\beta 1$ integrinfocal adhesion kinase (FAK). ${ }^{30}$ In addition, Liu, et al. $^{34}$ (2017) demonstrated in vivo that $316 \mathrm{~L}$ stainless steel treated with stromal cell-derived factor-1a (SDF-1a)/laminin had increased biocompatibility and improved the healing of vascular lesions. Enhanced adhesion, migration and proliferation of human limbal epithelial stem cells was also demonstrated in tests with specific isoforms of LM incorporated into a fibrin-based hydrogel. ${ }^{12}$ These positive effects of LM have been shown on Schwann cells ${ }^{33}$ as well as on hepatocytes and endothelial cells. ${ }^{11,13}$ Therefore, the results of the present study, in which LM stimulated the adhesion, proliferation and spreading on hAPCs, corroborate with these data previously reported by several researchers. ${ }^{11,12,13,33,35}$

This study also showed that the bioactive potential of 1,5 and $10 \mu \mathrm{g} / \mathrm{mL}$ of $\mathrm{FN}$ was concentrationdependent and promoted strong adhesion on hAPCs compared with the positive control and other experimental groups. Additionally, concentrations of 5 and $10 \mu \mathrm{g} / \mathrm{mL}$ of $\mathrm{FN}$ stimulated the highest 
proliferation and spreading of hAPCs at all time-points. These data are in line with a previous investigation in which the authors demonstrated an experimental hydrogel containing FN exerted higher chemotactic effect on NIH 3 T3 fibroblasts than the same hydrogel containing LM. ${ }^{32}$ The role of $F N$ in inducing cell migration and differentiation on dental pulp cells is already known. ${ }^{36,37}$ Chang, et al. ${ }^{38}$ (2016) evaluated the effect of titanium surfaces treated with glow discharge plasma followed by FN adsorption on MG-63 osteoblast-like cells. The authors observed that the modified titanium surfaces enhanced cell adhesion, migration and proliferation. Matsui, et al. ${ }^{28}$ (2015) also reported an increased cell adhesion in situ when FNcoated hydroxyapatite was assessed under a defined experimental condition. Amplified cell migration, adhesion, spreading and proliferation occurred when periodontal ligament cells were treated with 5 or 10 $\mu \mathrm{g} / \mathrm{mL}$ of fibronectin. ${ }^{27}$ More recently, Parisi, et al. ${ }^{15}$ (2020) demonstrated that high concentrations of fluid containing FN allowed rapid deposition of this protein on biomaterials, what improved the adhesion and proliferation of cells on them.

Taking into consideration all the interesting data concerning the positive effects of $\mathrm{FN}$ and LM on different cell lines and based upon the preliminary results obtained in this in vitro study, the two highest concentrations of FN and LM were selected for the subsequent experiments. In the present investigation, only the use of $10 \mu \mathrm{g} / \mathrm{mL}$ of $F N$ significantly increased the synthesis of total collagen, as well as gene expression and synthesis of type I collagen in comparison with the positive control. Despite the tendency towards increase in the expression of type III collagen, there was no significant difference between FN10 and the positive control. Collagen is an abundant protein in the extracellular matrix of pulp tissue, with type I and type III collagen representing about $56 \%$ and $41 \%$, respectively, of the organic content. ${ }^{31}$ Previous studies described the presence of FN in tissue engineering strategies as an approach to induce collagen synthesis and stimulate tissue regeneration. ${ }^{33,39}$ Collagen and other proteins present in the extracellular matrix have interaction sites with different specificities for cell membrane receptors, turning the cells capable of binding and triggering distinct biological activities related to development, homeostasis and formation of a new tissue. ${ }^{11}$

To better understand the mechanism of action of FN and LM on hAPCs, we also evaluated the gene expression of a5 integrin (ITGA5) and av integrin (ITGAV); these genes are related to cell migration and adhesion. ${ }^{25,40-42}$ The interaction of a5 $\beta 1$ and $\operatorname{av} \beta 3$ integrins and the role of these membrane receptors in the detection of extra-cellular matrix proteins have been demonstrated. ${ }^{42}$ Although these integrins have distinct biological intracellular mechanisms, both act in the detection processes of specific ligands that trigger particular cell signaling related to the projection mechanisms and directional migration of the cytoskeleton. The joint action of integrins allows cells to adapt to the microenvironment and perform their functions in tissue remodeling and regeneration. ${ }^{44}$ In the present study, we observed higher gene expression of ITGA5 and ITGAV only for FN10 in comparison with the positive control $(p<0.05)$. In a study conducted with a parental fibroblast lineage, Spoerri, et al. ${ }^{43}$ (2020) observed that when the $a 5 \beta 1$ and $a V \beta 3$ integrins were activated by PAR1 and PAR3 proteases, via GBY and PI3K signaling, they changed their conformation, thereby enhancing their affinity to FN. Thus, the cell adhesion established was strengthened by means of specific biological signals mediated by PARs via Ga13, Gai, ROCK and Src. Also, the authors reported the cell migration and proliferation were accelerated after cell adhesion was triggered. ${ }^{33}$ The effect of proteins that contain a functional domain of FN and LM was also observed in a primary culture of human keratinocytes. ${ }^{44}$ When these cells were subjected to GTPase inhibitors in the presence of FN and LM-mimic surfaces, the modulation of cell adhesion and migration was dependent on the Rac1 and Rho pathways. ${ }^{44}$ Nevertheless, in the presence of the a5 $\beta 1$ integrin receptor, FN-mimic was capable of inducing cell migration and increasing keratinocyte adhesion, whereas under these conditions, LM-mimic was unable to stimulate cell motility. ${ }^{44}$ Therefore, we could suggest that the type and concentration of the ECMp influence the cell adhesion and migration, and at least partly explain the strong bioactive potential of $10 \mu \mathrm{g} / \mathrm{mL}$ of $F N$ on the HAPCs observed in the present study.

Overall, the need to replace the traditional endodontic treatment of teeth with incomplete root formation (which aims to induce apexification and later fill the root canal with definitive materials), has led to the hypothesis that associating the bioactive properties of FN with those of an interesting biomaterial can 
regenerate the lost pulp tissue. Previous studies have shown that the association of extracellular matrix proteins with scaffolds approximated the conditions of the in vivo environment. ${ }^{13,29,33}$ Thus, they mediated the mechanical-chemical signals in the processes of adhesion, migration, proliferation and differentiation of various cell types, and in the synthesis of a new matrix. ${ }^{13,29,33}$ The results obtained in the present study cannot be directly extrapolated to clinical situations. However, in spite of the limitations of this laboratory investigation, it seems appropriate to conduct further studies to assess techniques using the cell-free approaches proposed by Galler and Widbiller ${ }^{7}$ (2020). In these, the root canals may be filled with biomaterials containing dosages of $\mathrm{FN}$ fibronectin capable of stimulating the migration of cells from apical papilla and allowing new pulp-like tissue formation.

\section{Conclusions}

According to the methodologies used in the present study, we conclude that $10 \mu \mathrm{g} / \mathrm{mL}$ of fibronectin could act as a potent bioactive agent for human apical papilla cells by inducing cell adhesion, proliferation, spreading and collagen synthesis.

\section{Acknowledgments}

The authors would like to thank the Fundação de Amparo à Pesquisa do Estado de São Paulo (\#2017/14210-8; \#2017/22739-9) and the Conselho Nacional de Desenvolvimento Científico e Tecnológico (\# 302047/2019-0; \# 408721/2018-9).

\section{Authors' contributions}

Leite, Maria Luísa: Conceptualization (Equal); Formal analysis (Supporting); Investigation (Lead); Methodology (Lead); Software (Supporting); Writingoriginal draft (Lead). Soares, Diana Grabiela: Conceptualization (Equal); Methodology (Supporting). Anovazzi, Giovana: Methodology (Supporting). Mon, Filipe Koon Wu: Methodology (Supporting). Bordini, Ester Alves Ferreira: Methodology (Supporting). Hebling, Josimeri: Formal analysis (Lead); Software (Lead); Validation (Lead). Costa, Carlos Alberto de Souza: Corresponding Author; Conceptualization (Equal); Funding acquisition (Lead); Supervision (Lead); Writing-review \& editing (Lead).

\section{References}

1- Nagy MM, Tawfik HE, Hashem AA, Abu-Seida AM. Regenerative potential of immature permanent teeth with necrotic pulps after different regenerative protocols. J Endod. 2014;40(2):192-8. doi: 10.1016/j.joen.2013.10.027

2- Dissanayaka WL, Hargreaves KM, Jin L, Samaranayake LP, Zhang C. The interplay of dental pulp stem cells and endothelial cells in an injectable peptide hydrogel on angiogenesis and pulp regeneration in vivo. Tissue Eng Part A. 2015;21(3-4):550-63. doi: 10.1089/ten. TEA.2014.0154

3- Li X, Ma C, Xie X, Sun H, Liu X. Pulp regeneration in a full-length human tooth root using a hierarchical nanofibrous microsphere system. Acta Biomater. 2016;35:57-67. doi: 10.1016/j.actbio.2016.02.040 4- Zhang S, Zhang W, Li Y, Ren L, Deng H, Yin X, et al. Cotransplantation of human umbilical cord mesenchymal stem cells and endothelial cells for angiogenesis and pulp regeneration in vivo. Life Sci. 2020;255:117763. doi: 10.1016/j.Ifs.2020.117763

5- Albuquerque MT, Valera MC, Nakashima M, Nör JE, Bottino MC. Tissue-engineering-based strategies for regenerative endodontics. J Dent Res. 2014;93(12):1222-31. doi: 10.1177/0022034514549809 6- Diogenes A, Hargreaves KM. Microbial modulation of stem cells and future directions in regenerative endodontics. J Endod. 2017;43(9S):S95-101. doi: 10.1016/j.joen.2017.07.012

7- Galler KM, Widbiller M. Cell-free approaches for dental pulp tissue engineering. J Endod. 2020;46(9S):S143-9. doi: 10.1016/j. joen.2020.06.034

8- Steindorff MM, Lehl H, Winkel A, Stiesch M. Innovative approaches to regenerate teeth by tissue engineering. Arch Oral Biol. 2014;59(2):15866. doi: 10.1016/j.archoralbio.2013.11.005

9- Duarte PC, Gomes-Filho JE, Ervolino E, Sundefeld ML, Tadahirowayama $M$, Lodi CS, et al. Histopathological condition of the remaining tissues after endodontic infection of rat immature teeth. J Endod. 2014;40(4):538-42. doi: 10.1016/j.joen.2013.09.015

10- Iorio V, Troughton LD, Hamill KJ. Laminins: Roles and utility in wound repair. Adv Wound Care (New Rochelle). 2015;4(4):250-63. doi: 10.1089 /wound.2014.0533

11- Theocharis AD, Skandalis SS, Gialeli C, Karamanos NK. Extracellular matrix structure. Adv Drug Deliv Rev. 2016;97:4-27. doi: 10.1016/j. addr.2015.11.001

12- Polisetti N, Sorokin L, Okumura N, Koizumi N, Kinoshita S, Kruse FE, et al. Laminin-511 and -521-based matrices for efficient ex vivo-expansion of human limbal epithelial progenitor cells. Sci Rep. 2017;7(1):5152. doi: 10.1038/s41598-017-04916-x

13- Sivaraman K, Shanthi C. Matrikines for therapeutic and biomedical applications. Life Sci. 2018;214:22-33. doi: 10.1016/j.Ifs.2018.10.056 14- Bullard JD, Lei J, Lim JJ, Massee M, Fallon AM, Koob TJ. Evaluation of dehydrated human umbilical cord biological properties for wound care and soft tissue healing. J Biomed Mater Res B Appl Biomater. 2019;107(4):1035-46. doi: 10.1002/jbm.b.34196

15- Parisi L, Toffoli A, Ghezzi B, Mozzoni B, Lumetti S, Macaluso GM. A glance on the role of fibronectin in controlling cell response at biomaterial interface. Jpn Dent Sci Rev. 2020;56(1):50-5. doi: 10.1016/j.jdsr.2019.11.002

16- Kwon YS, Lee SH, Hwang YC, Rosa V, Lee KW, Min KS. Behaviour of human dental pulp cells cultured in a collagen hydrogel scaffold cross-linked with cinnamaldehyde. Int Endod J. 2017;50(1):58-66. doi: $10.1111 /$ iej.12592

17- Song JS, Takimoto K, Jeon M, Vadakekalam J, Ruparel NB, Diogenes A. Decellularized human dental pulp as a scaffold for regenerative endodontics. J Dent Res. 2017;96(6):640-6. doi: 10.1177/0022034517693606

18- Matoug-Elwerfelli M, Duggal MS, Nazzal H, Esteves F, Raïf E. A biocompatible decellularized pulp scaffold for regenerative endodontics. Int Endod J. 2018;51(6):663-73. doi: 10.1111/iej.12882 
19- Conant CG, Nevill JT, Zhou Z, Dong JF, Schwartz MA, IonescuZanetti $C$. Using well-plate microfluidic devices to conduct shear-based thrombosis assays. J Lab Autom. 2011;16(2):148-52. doi: 10.1016/j. jala.2010.10.005

20- Shi X, Yang J, Cui X, Huang J, Long Z, Zhou Y, et al. Functional effect of the mutations similar to the cleavage during platelet activation at integrin $\beta 3$ cytoplasmic tail when expressed in mouse platelets. PLoS One. 2016;11(11):e0166136. doi: 10.1371/journal.pone.0166136 21- Hayes V, Johnston I, Arepally GM, McKenzie SE, Cines DB, Rauova L, et al. Endothelial antigen assembly leads to thrombotic complications in heparin-induced thrombocytopenia. J Clin Invest. 2017;127(3):1090-8. doi: $10.1172 /$ JCI90958

22- Leite ML, Soares DG, Duque CC, Bordini EA, Anovazzi G, Basso FG, et al. Positive influence of simvastatin used as adjuvant agent for cavity lining. Clin Oral Investig. 2019;23(9):3457-69. doi: 10.1007/ s00784-018-2757-7

23- Soares DG, Anovazzi G, Bordini EAF, Zuta UO, Silva Leite ML, Basso FG, et al. Biological analysis of simvastatin-releasing chitosan scaffold as a cell-free system for pulp-dentin regeneration. J Endod. 2018;44(6):971-6.e1. doi: 10.1016/j.joen.2018.02.014

24- Barros SA, Soares DG, Leite ML, Basso FG, Costa CAS, Adabo $\mathrm{GL}$. Influence of zirconia-coated bioactive glass on gingival fibroblast behavior. Braz Dent J. 2019;30(4):333-41. doi: 10.1590/01036440201902417

25- Kim HY. Statistical notes for clinical researchers: Sample size calculation 1. comparison of two independent sample means. Restor Dent Endod. 2016;41(1):74-8. doi: 10.5395/rde.2016.41.1.74

26- Gupte MJ, Ma PX. Nanofibrous scaffolds for dental and craniofacial applications. J Dent Res. 2012;91(3):227-34. doi: 10.1177/0022034511417441

27- Kapila $\mathrm{YL}$, Lancero $\mathrm{H}$, Johnson PW. The response of periodontal ligament cells to fibronectin. J Periodontol. 1998;69(9):1008-19. doi: 10.1902/jop.1998.69.9.1008

28- Matsui N, Nozaki K, Ishihara K, Yamashita K, Nagai A. Concentrationdependent effects of fibronectin adsorbed on hydroxyapatite surfaces on osteoblast adhesion. Mater Sci Eng C Mater Biol Appl. 2015;48:378-83. doi: 10.1016/j.msec.2014.12.042

29- Tang J, Saito T. Human plasma fibronectin promotes proliferation and differentiation of odontoblast. J Appl Oral Sci. 2017;25(3):299309. doi: 10.1590/1678-7757-2016-0442

30- Suzuki N, Hyodo M, Hayashi C, Mabuchi Y, Sekimoto K, Onchi C, et al. Laminin a2, a4, and a5 chains positively regulate migration and survival of oligodendrocyte precursor cells. Sci Rep. 2019;9(1):19882. doi: 10.1038/s41598-019-56488-7

31- Goldberg M, Farges JC, Lacerda-Pinheiro S, Six N, Jegat N, Decup $F$, et al. Inflammatory and immunological aspects of dental pulp repair. Pharmacol Res. 2008;58(2):137-47. doi: 10.1016/j.phrs.2008.05.013
32- Hartman CD, Isenberg BC, Chua SG, Wong JY. Extracellular matrix type modulates cell migration on mechanical gradients. Exp Cell Res. 2017;359(2):361-6. doi: 10.1016/j.yexcr.2017.08.018

33- Beyeler J, Katsaros C, Chiquet M. Impaired contracture of 3D collagen constructs by fibronectin-deficient murine fibroblasts. Front Physiol. 2019;10:166. doi: 10.3389/fphys.2019.00166

34- Liu T, Wang $X$, Tang $X$, Gong $T$, Ye W, Pan $C$, et al. Surface modification with ECM-inspired SDF-1a/Laminin-loaded nanocoating for vascular wound healing. ACS Appl Mater Interfaces. 2017;9(36):3037386. doi: 10.1021/acsami.7b08516

35- Motta CM, Endres KJ, Wesdemiotis C, Willits RK, Becker ML. Enhancing Schwann cell migration using concentration gradients of laminin-derived peptides. Biomaterials. 2019;218:119335. doi: 10.1016/j.biomaterials.2019.119335

36- Tziafas D, Alvanou A, Kaidoglou K. Dentinogenic activity of allogenic plasma fibronectin on dog dental pulp. J Dent Res. 1992;71(5):118995. doi: 10.1177/00220345920710051101

37- Tziafas D. Basic mechanisms of cytodifferentiation and dentinogenesis during dental pulp repair. Int J Dev Biol. 1995;39(1):281-90. 38- Chang YC, Lee WF, Feng SW, Huang HM, Lin CT, Teng NC, et al. In vitro analysis of fibronectin-modified titanium surfaces. PLoS One. 2016;11(1):e0146219. doi: 10.1371/journal.pone.0146219 39- Ramaswamy AK, Vorp DA, Weinbaum JS. Functional vascular tissue engineering inspired by matricellular proteins. Front Cardiovasc Med. 2019;6:74. doi: 10.3389/fcrm.2019.00074

40- Zhu Q, Safavi KE, Spångberg LS. Integrin expression in human dental pulp cells and their role in cell attachment on extracellular matrix proteins. J Endod. 1998;24(10):641-4. doi: 10.1016/S00992399(98)80145-3

41- Rapuano BE, Lee JJ, MacDonald DE. Titanium alloy surface oxide modulates the conformation of adsorbed fibronectin to enhance its binding to $a(5) \beta(1)$ integrins in osteoblasts. Eur J Oral Sci. 2012;120(3):185-94. doi: 10.1111/j.1600-0722.2012.954.x

42- Diaz C, Neubauer S, Rechenmacher F, Kessler H, Missirlis D. Recruitment of av $\beta 3$ integrin to a5 $\beta 1$ integrin-induced clusters enables focal adhesion maturation and cell spreading. J Cell Sci. 2020;133(1):jcs232702. doi: 10.1242/jcs.232702

43- Spoerri PM, Strohmeyer N, Sun Z, Fässler R, Müller DJ. Proteaseactivated receptor signalling initiates a5 $\beta 1$-integrin-mediated adhesion in non-haematopoietic cells. Nat Mater. 2020;19(2):218-26. doi: 10.1038/s41563-019-0580-4

44- Chen WW, Tjin MS, Chua AWC, Lee ST, Tay CY, Fong E. Probing the role of integrins in keratinocyte migration using bioengineered extracellular matrix mimics. ACS Appl Mater Interfaces. 2017;9(42):36483-92. doi: 10.1021/acsami.7b06959 